\title{
Shallow Groundwater Conservation Based Empowerment and its Influence Factors by Groundwater User Farmers in Takalar Regency
}

\author{
Darwis $^{1^{*}}$, Rakhim Nanda ${ }^{1}$, Muhammad Ardi ${ }^{2}$, Lahming ${ }^{2}$, and Muhammad Arsyad ${ }^{3}$ \\ ${ }^{1}$ Engineering Faculty, Muhammadiyah University of Makassar, Indonesia \\ ${ }^{2}$ Engineering Faculty, Makassar State University, Indonesia \\ ${ }^{3}$ Matematics and Science Faculty, Makassar State University, Indonesia
}

"Corresponding author: Darwis, Engineering Faculty, Muhammadiyah University of Makassar, Indonesia, Tel: +62 411 866972; E-mail: darwis_unismuhmks@yahoo.com

Rec date: Oct 29, 2014, Acc date: Jan 12, 2015, Pub date: Jan 14, 2015

Copyright: @ 2015 Darwis, et al. This is an open-access article distributed under the terms of the Creative Commons Attribution License, which permits unrestricted use, distribution, and reproduction in any medium, provided the original author and source are credited.

\begin{abstract}
This study is an initial stage in an effort to conserve groundwater by employing skills and self-reliance of groundwater user farmers where the groundwater is utilized to irrigate farm. Before carrying out community empowerment, specifically for marginal community, the researcher shall be able to recognize some factors that affect target's empowerment. Accordingly, empowerment model formulation which can be made representatively shall in conformity with reality to empowered target community.

To examine level of influence of every observed factor in this study, it applies instrument through Gutmann scale. Scales of applied instrument in the study is answers of YES or NO. The instrument is adapted by vary educational background of the farmers.

For all identified factors in the study, there are 6 factors that affect significantly groundwater user farmer empowerment level in their effort to conserve groundwater independently and collectively. Factors indicating significant influence are: (1) agricultural input, (2) environmental potential, (3) technical aid, (4) farmer organization, (5) farmers' rights and (6) democratization of farmers.
\end{abstract}

Keywords: Shallow groundwater; Influence factors of empowerment; Groundwater users farmers

\section{Introduction}

Groundwater is exploited to fulfill various kinds of needs and interest of humankind such as clean water, water needs for irrigation, recreation, mining, and so forth. Consequently, the existence of groundwater is more at risk of becoming endangered along with world population growth and increase of human activities and interest variance in an effort to meet their needs and interests [1]. Groundwater will be more at critical condition if exploitation is conducted based on utilitarianism ethics (homocentric) which always put community interest forward instead of environment viability. What is worse in activities of exploitation then, is when groundwater users take egocentric point of view in which they always exploits the natural resources based on individual necessities and focused on what is good for them [2].

Existence of water in the ground layer is very important because it affects the characteristics and stability of soil (abiotic) and the balance of nature (biotic) either on or underground environment [1]. The nature of fluid will always form surface equilibrium; accordingly, every action that disturbs groundwater equilibrium will be responded by new equilibrium formation, and this formation, then, will affect surrounding environment.

Takalar Regency as one of regions with most population working as farmer, geologically, is quite lucky because this region is in groundwater basin region with its very potential groundwater. Almost all lowland regions in Takalar Regency from coastal area to foot of mountain are inside groundwater basin zone. Since at the beginning of 1980s, Department of Agriculture of Takalar Regency introduced groundwater irrigation by systems of pumps, and there were quite a lot of farmers who exploit groundwater to fulfill water needs for their cultivated crops, especially in dry season [2].

Ministerial Regulation of Indonesian Minister of Agriculture No. 79 of 2012 regarding Guidance and Empowerment Guidelines for Water User Farmer Organization outlines five goals to be achieved by the regulation, they are [3]: 1) To improve capability of Water User Farmer Organization as farmer organization in performing functions of irrigation canal management in tertiary plot/farmer business level; 2) To improve self-reliance of Water User Farmer Organization in irrigation technique, social, economy, and organization that they will have an active role in development and management of participative irrigation system; 3) To improve irrigation distribution services for farmers who are the member of Water User Farmer Organization in carrying out agricultural business; 4) To improve skills of Water User Farmer Organization in establishing cooperation with outside parties, including regional government or other institution, for the interests of members; and 5) To improve role of farmers in establishing participative irrigation from planning, execution, rehabilitation, operation and maintenance of irrigation canals, and water resources management for food production escalation and rural agriculture interests. All substances embodied in the Ministerial Regulations are oriented toward an effort to increase agricultural production by 
Citation: Darwis, Rakhim N, Muhammad A, Lahming, Muhammad A (2015) Shallow Groundwater Conservation Based Empowerment and its Influence Factors by Groundwater User Farmers in Takalar Regency. Hydrol Current Res 6: 802. doi:10.4172/2157-7587.1000187

Page 2 of 4

utilizing groundwater, with no intention to conserve groundwater existence and this resources viability.

The findings of Darwis et al. [1] found that groundwater condition in Takalar has been at degradation, either degradation of groundwater lever or salinity. Thus, groundwater recovery in this area is an urgent demand. It shall be made farmers aware of a possibility if the groundwater were not conserved right now; it would be nothing left in their land that the future generations could not farm by utilizing groundwater as they do today. If the concept and awareness are built up along with knowledge and skills they need to be actively participated in groundwater conservation for their own land, shallow groundwater conservation and farm business viability will be maintained chronically from generations to generations.

Farmer empowerment, in general, has a structural weakness on farmer side [4]. According to Sri Nuryanti [5], problems faced by farmers are generally caused by capital. Consequently, the use of agricultural production equipment is low that makes inefficiency in business. This problem arises because their land is commonly narrow, and when they have short of money, their bargaining power at harvest time is going to be weakened. Besides, the agricultural products are low quality as driven by farmers' orientation for family needs compliance (subsistence agriculture) [6].

\section{Research Method}

To formulate farmer empowerment model in Takalar Regency in an effort to conserve shallow groundwater, the study will analyze some factors (variables) which may have significant influence on farmer empowerment effectiveness for groundwater conservation, they are: (1) agricultural inputs, (2) environmental potential, (3) technical aid, (4) farmer organization, (5) farmers' rights, and (6) democratization of farmers [7].

Agricultural inputs are agricultural equipment's or machine such as sickle, hoe, plough, sprayer, tractor, pump, irrigation and so forth. It also includes agricultural production means, for example seed, fertilizer, pesticide and growth regulating substances, etc. 3]. Environmental potential is environment capacity that covers natural resources which can be employed to carry out farm business and farmer activities to achieve optimum goals [7]. Technical aid is proposed opinion or suggestion to be taken into consideration as solution that is addressed to solve problems faced by them. Suggestion shall be constructive, educative, objective and in accordance with the discussed topic. Technical, then, is knowledge and skills to build up something based on the design (engineering) [7]. Farmer organization is an association of farmers which is established on the basis of similarities in interests, environment (social, economy, and resources) and intimacy with the goals of escalating and developing members' farm business [7]. Farmers' rights is fundamental rights for farmers in purpose to gain access to get, to own, to utilize and to maintain the agricultural land that will be or had been possessed. Democratization of agriculture is agricultural development process that involves farmers collectively, with equal rights to work with the government, college, non-governmental organization, and/or donor organization to carry out development stages starting from identification of potential, planning, execution, monitoring and evaluation toward the success of implemented program [7].

\section{Research Design}

Research design applied herein is observation which is carried out by using written instrument to assess influence scale of the factors that affect groundwater user farmer empowerment level in their effort to conserve groundwater independently (Figure 1).

Relationship scheme for factors that affect farmer empowerment level in groundwater conservation can be illustrated as follows:

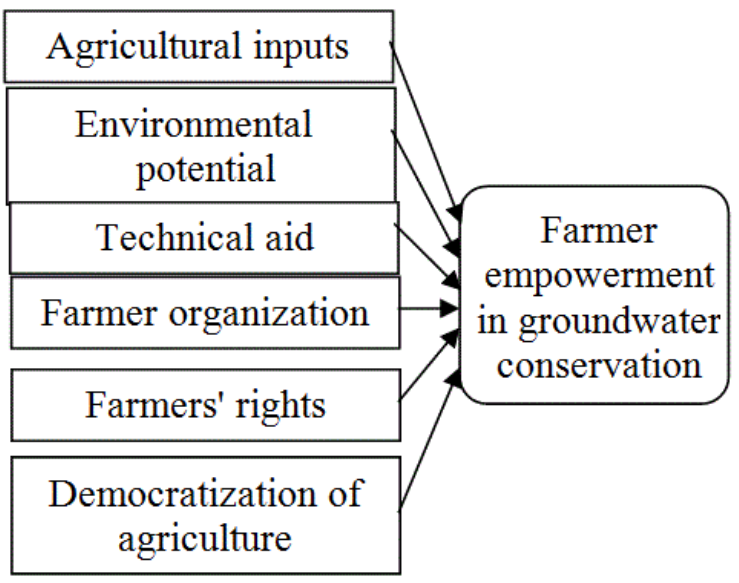

Figure 1: Relationship scheme of variables

It is necessary to know strength of influence of the six observed factors on groundwater user farmer empowerment level in Takalar before carrying out groundwater conservation collectively and independently.

The six influence factors are outlined in form of closed questions, and these questions are given to every farmer (respondent) from which they are groundwater user farmers who use it for irrigation. Question details are follows: (1) influence factor of agricultural inputs; it is used to describe the existence of agricultural input relating to groundwater utilization and it consists of 5 questions; (2) influence factor of environmental potential which is used to describe condition of environmental potential in agricultural land regarding groundwater utilization, it consists of 5 questions; (3) influence factor of technical aid; it functions to describe existence and urgency of guidance/ counseling to farmers relating to groundwater utilization, it consists of 5 questions; (4) influence factor of farmer organization; it is used to describe existence and urgency of farmer organization relating to groundwater utilization and it has 5 questions; (5) influence factor of farmers rights which is used to describe existence of farmers rights either individual or group rights, it is outlined in 5 questions; and (6) influence factor of democratization of agriculture which outlines proportional and effective groundwater utilization conducted by farmers, it consists of 5 questions.

\section{Data Collection}

Product of observation by using instrument consisting of 6 observed influence factors becomes primary data that afterwards, it will be processed and analyzed to describe the real condition in field. In this study, secondary data is ignored in purpose to eliminate 
Citation: Darwis, Rakhim N, Muhammad A, Lahming, Muhammad A (2015) Shallow Groundwater Conservation Based Empowerment and its Influence Factors by Groundwater User Farmers in Takalar Regency. Hydrol Current Res 6: 802. doi:10.4172/2157-7587.1000187

Page 3 of 4

subjective data, either the data from the local government as data provider, or subjectivity of researcher.

\section{Data Processing}

Data processing is carried out descriptively by using closed instrument which is distributed to 30 respondents of groundwater user farmers. Data found by observation, then, will be examined by instrument reliability test and validity test. Construct validity is applied by calculating product moment coefficient (rxy) and the equation below [8]:

$$
r_{X y}=\frac{n \cdot \sum X i \cdot Y i-\left(\sum X i\right)\left(\sum Y i\right)}{\sqrt{\left\{n \sum X i^{2}-\left(\sum X i\right)^{2}\right\} \cdot\left\{n \cdot \sum Y i^{2}-\left(\sum Y i\right)^{2}\right\}}}
$$

Information:

$$
\mathrm{n}=\text { Amount of respondents }
$$

$\mathrm{Xi}=$ Item score of the ith respondent

$\mathrm{Yi}=$ Total score of the ith respondent

rxy=product moment coefficient

\section{Instrument item is valid if score of $r x y \geq 0.30$}

Due to form of observation instrument is Yes - No question, the exact formula to be used to assess reliability grade is KR-10 (Kuder Richardson) as follows 8]:

$$
r_{i}=\frac{k}{(k-1)}\left\{\frac{S t^{2}-\sum p_{i} \cdot q_{i}}{S t^{2}}\right\}
$$

Information:

\section{$\mathrm{k}=$ Amount of instrument items}

$\mathrm{pi}=$ Proportion of respondents who answer the ith item

qi=1-pi

$\mathrm{St}=$ Total variant

ri=Internal reliability of all instruments

Instruments in a whole are reliable if value of ri $\geq 0.30$

\section{Data Analysis}

To assess strength level of influence factor on groundwater user farmer empowerment in conserving groundwater collectively and independently, processing data toward observation output is conducted by inferential statistics method by applying t-test formula as follows [9]:

$$
t=\frac{\bar{X} 1-\bar{X} 2}{\sqrt{\frac{s 1^{2}}{n 1}+\frac{s 2^{2}}{n 2}-2 \cdot r \cdot\left(\frac{s 1}{\sqrt{n 1}}\right)\left(\frac{s 2}{\sqrt{n 2}}\right)}}
$$

Information:

$\overline{X_{1}}=$ Average treatment group sample $\overline{X_{2}}=$ Average control group sample

$$
\begin{aligned}
& \mathrm{n}_{1}=\text { Amount of treatment group sample } \\
& \mathrm{n}_{2}=\text { Amount of control group sample } \\
& \mathrm{s}_{1}=\text { Standard deviation of treatment group sample }
\end{aligned}
$$

$$
\begin{aligned}
& \mathrm{s}_{2}=\text { Standard deviation of control group sample } \\
& \mathrm{s}_{1}^{2}=\text { Variance of treatment group sample } \\
& \mathrm{s}_{1}{ }^{2}=\text { Variance of control group sample } \\
& \mathrm{r}=\text { correlation between two sample groups }
\end{aligned}
$$

To assess strength level of every influence factor, score of $t$-count from the formula will be compared by value of $t$-table at significance level of $\alpha=0.05$ and degrees of freedom of 30 .

\section{Research Findings}

Based on data analysis, some findings are detailed below:

Statistical value of agricultural inputs to farmer empowerment in groundwater conservation found that $\mathrm{t}$-count is 1.96 . Taken from the table, degree of freedom is $30 . \mathrm{t}-0.95=-1.70$ to +1.70 . If Ho is rejected and $\mathrm{Ha}$ is accepted, it indicates that agricultural inputs factor has significant influence on farmer empowerment to carry out groundwater conservation collectively and independently.

Statistical value of environmental potential factor to farmer empowerment in groundwater conservation found that $\mathrm{t}$-count is 2.21 . Taken from the table, degree of freedom is $30 . t-0.95=-1.70$ to +1.70 . If $\mathrm{Ho}$ is rejected and $\mathrm{Ha}$ is accepted, it indicates that environmental potential factor has significant influence on farmer empowerment to carry out groundwater conservation collectively and independently.

Statistical value of technical aid factor to farmer empowerment in groundwater conservation found that $\mathrm{t}$-count is 2.08 . Taken from the table, then, degree of freedom is 30 . $\mathrm{t}-0.95=-1.70$ to +1.70 . If Ho is rejected and $\mathrm{Ha}$ is accepted, it indicates that technical aid factor has significant influence on farmer empowerment to carry out groundwater conservation collectively and independently.

Statistical value of farmer organization factor to farmer empowerment in groundwater conservation found that $\mathrm{t}$-count is 2.19 . Taken from the table, degree of freedom is 30 . $t-0.95=-1.70$ to +1.70 . If $\mathrm{Ho}$ is rejected and $\mathrm{Ha}$ is accepted, it indicates that farmer organization factor has significant influence on farmer empowerment to carry out groundwater conservation collectively and independently.

Statistical value of farmers' rights factor to farmer empowerment in groundwater conservation found that $\mathrm{t}$-count is 1.88 . Taken from the table, degree of freedom is $30 . \mathrm{t}-0.95=-1.70$ to +1.70 . If Ho is rejected and $\mathrm{Ha}$ is accepted, it indicates that farmers' rights factor has significant influence on farmer empowerment to carry out groundwater conservation collectively and independently.

Statistical value of democratization of farmers factor to farmer empowerment in groundwater conservation found that $\mathrm{t}$-count is 1.92. Taken from the table, degree of freedom is $30 . t-0.95=-1.70$ to +1.70 . If $\mathrm{Ho}$ is rejected and $\mathrm{Ha}$ is accepted, it indicates that democratization of farmers factor has significant influence on farmer empowerment to carry out groundwater conservation collectively and independently.

\section{Discussion}

\section{Influence factor of agricultural inputs}

Agricultural inputs factor is one of factors having sufficient effect on groundwater user farmer's ability to conserve groundwater. The presence of equipment's and materials to carry out groundwater conservation will lift up work motivation of the farmers. 
Citation: Darwis, Rakhim N, Muhammad A, Lahming, Muhammad A (2015) Shallow Groundwater Conservation Based Empowerment and its Influence Factors by Groundwater User Farmers in Takalar Regency. Hydrol Current Res 6: 802. doi:10.4172/2157-7587.1000187

Page 4 of 4

\section{Influence factor of environmental potential}

It is one of factors that affect fairly great groundwater user farmer's ability to conserve groundwater. Condition of environmental potential, especially the existence of groundwater which has been at degradation, will lift up farmer awareness to take participation at groundwater conservation action.

\section{Influence factor of technical aid}

It is one of factors that have sufficient effect on groundwater user farmer's ability to conserve groundwater. Suggestion, information, guidance and counseling from outside party will enhance farmer's knowledge and attitude to participate in groundwater conservation action.

\section{Influence factor of farmer organization}

It is one of factors that affect fairly great groundwater user farmer's ability to conserve groundwater. The presence of association to guide farm business development will make farmer do an action, have an attitude, and take participation in groundwater conservation.

\section{Influence factor of farmers' rights}

It is one of factors that affect fairly great groundwater user farmer's ability to conserve groundwater. Admission and acceptance of farmer's existence and their rights on sufficient agricultural land will provide a sense of security and possession that will make them actively participate in performing groundwater conservation.

\section{Influence factor of democratization of agriculture}

Democratization of agriculture is one of factors that have fair effect on groundwater user farmer's ability to conserve groundwater. Farmer involvement in making decision that has direct relationship with their activities and profession will establish their confidence and optimism to actively participate in groundwater conservation.

\section{Conclusion}

Based on the observation toward factors that affect groundwater user farmer empowerment in Takalar Regency, in purpose to carry out groundwater conservation collectively and independently, some conclusion can be made below:

There are 6 (six) factors that affect significantly groundwater user farmer empowerment to conserver groundwater, they are: agricultural inputs, environmental potential, technical aid, farmer organization, farmers' rights and democratization of agriculture.
Significance levels of the influence factors are different; the factors are made in list as follows: (1) environmental potential; (2) farmer organization; (3) technical aid; (4) agricultural inputs; (5) democratization of agriculture; (6) farmers' rights.

\section{Suggestion}

It is still that the study has some weaknesses. It is caused by some factors that were not observed, such as educational background of the farmers, farmer behavior in groundwater conservation and so forth.

Therefore, the researcher suggests some tips for the upcoming research as follows:

The study shall observe the influence of farmer's educational background in their effort to conserve groundwater in collective and independent manner in Takalar Regency.

The study shall observe the influence of guidance and counseling on groundwater user farmers in their collective and independent effort of groundwater conservation in Takalar Regency.

\section{References}

1. Alawneh R, Al-Salihi A, Rimawi OA, Abed AM (2011) Modeling of Groundwater Recharge by Rainwater Harvesting - Wadi Bayer (Case Study). Jordan Journal of Civil Engineering, 5: 191-209.

2. Darwis, Rakhim N, Muhammad A, Lahming, Muhammad A (2012) Pemodelan Formasi Sumur Resapan untuk Recovery Air Tanah dan Pencegahan Intrusi Air Laut ke Lapisan Tanah pada Lahan Pertanian di Kabupaten Takalar, Laporan Hasil Penelitian Hibah Bersaing Depdikbud.

3. Zulkarnaen RI (2012) Peraturan Menteri Pertanian No.79/ Permentan/OT.140/ 12/2012, tentang Pedoman Pembinaan dan Pemberdayaan Perkumpulan Petani Pemakai Air.

4. Hadi Agus P (2010) Konsep Pemberdayaan, Partisipasi dan Kelembagaan Dalam Pembangunan. Yayasan Agribisnis/Pusat Pengembangan Masyarakat Agrikarya (PPMA).

5. Herman B (2002) Artificial recharge of groundwater: hydrogeology and engineering. Hydrogeology Journal 10:121-142.

6. Nuryanti S (2005) Pemberdayaan Petani dengan Model Cooperative Farming. Jurnal Analisis Kebijakan Pertanian, 3: 152-158.

7. (2004) Farmer Empowerment, Technical Advisor Service DANIDA (Danish International Development Agency).

8. Djaali D, Pudji M (2007) Pengukuran dalam Bidang Pendidikan. Jakarta: Grasindo.

9. Sugiyono (2012) Statistik untuk Penelitian. Cetakan ke-24. Alfabeta, Bandung. 